\title{
HUMAN PAPILLOMAVIRUS INFECTION IN WOMEN ATTENDED AT A CERVICAL CANCER SCREENING SERVICE IN NATAL, BRAZIL
}

\author{
Thales Allyrio Araújo de Medeiros Fernandes ${ }^{2}$; Rosely de Vasconcellos Meissner ${ }^{1}$; Laelson Freire Bezerra ${ }^{3}$; \\ Paulo Roberto Medeiros de Azevedo ${ }^{4}$; José Veríssimo Fernandes ${ }^{1 *}$
}

\author{
${ }^{1}$ Departamento de Microbiologia e Parasitologia, Universidade Federal do Rio Grande do Norte, Natal, RN, Brasil; \\ ${ }^{2}$ Departamento de Ciências Biomédicas, Universidade do Estado do Rio Grande do Norte, Mossoró, RN, Brasil; ${ }^{3}$ Hospital Luiz \\ Antônio, Natal, RN, Brasil; ${ }^{4}$ Departamento de Estatística, Universidade Federal do Rio Grande do Norte, Natal, RN, Brasil
}

Submitted: July 20, 2007; Returned to authors for corrections: December 20, 2007; Approved: July 06, 2008.

\begin{abstract}
We analyzed cervical specimens of 202 women, aged 15 to 64 years, attended at Luis Antonio Hospital, Natal, Brazil, to determine the prevalence of HPV and identify the more frequent genotypes and risk factors for HPV infection in women attended at a cervical cancer screening service. Two specimens were collected from each patient: one for cytological examination and the other to detect HPV DNA by PCR, and typing by dot blot hybridization. A total of $54.5 \%$ of the sample had normal cytology and $45.5 \%$ had cytological alterations. HPV was detected in $24.5 \%$ of the cytologically normal women and in $59.8 \%$ of those with altered cytology. Both single and double HPV infection increased the likelihood of cytological alterations. Thirteen types of HPV were identified, most of which were high risk. HPV 16 was the most prevalent single-type infection, followed by HPV 58. The most frequent double infection was the association between HPV 56 and 57 . The prevalence of HPV in cytologically normal women was greater than that reported for countries on all the continents except Africa. The inverse was observed in women with cytological alterations. The distribution of HPV types was similar to that described for the Americas, with some differences. Multiple sexual partners was the only risk factor showing an association with the presence of HPV infection.
\end{abstract}

Key-words: Human papillomavirus, Cervical cancer, Epidemiology, Prevalence, Risk factors

\section{INTRODUCTION}

The human papillomavirus (HPV) infection is one of the main causes of sexually transmitted diseases in the world, especially in developing countries, where the prevalence of the asymptomatic form varies from 2 to $44 \%$, depending on the population (2). Evidence shows that most sexually active individuals are exposed to infection from this virus at some moment in their lives $(1,24)$.

HPV infection is most prevalent in young adults, at the start of their sexual life. A subsequent decline in the prevalence of the virus occurs with increasing age, likely as a result of development of an adaptive immune response against the virus $(5,15)$. Among the risk factors for HPV infection are the following: age at first sexual intercourse, number of sexual partners, parity, smoking and other sexually transmissible infections. Moreover, oral contraceptive use, immune and nutritional status, and genetic background of the host are also considered risk factors for HPV infection $(1,24)$.

More than 120 different HPV types have been catalogued so far, and about 40 can infect the epithelium of the anogenital tract and other mucosal areas of the body. At least 15 of these, called oncogenic or high-risk HPV (HR-HPV), are strongly associated with progression to invasive cervical cancer (18). The most prevalent type found in all the studies was HPV 16. However, the prevalence of both HPV 16 and the other types differs considerably according to the degree of the cervical lesion and the geographic region (6).

*Corresponding Author. Mailing address: Universidade Federal do Rio Grande do Norte, Departamento de Microbiologia e Parasitologia, Centro de Biociências - Campus Universitário, Lagoa Nova, 59072-970, Natal, RN. Tel.: 84-32153437. E-mail: veris@cb.ufrn.br 
Although most HPV infection resolves spontaneously, a small fraction of infected individuals, known as chronic or persistent carriers, will retain the virus without exhibiting any clinical manifestation. It is now well established that persistent infection by HR-HPV is a necessary condition, although it is not enough to provoke the development of cervical cancer and its precursor lesions $(3,26)$.

Geographic variations on HPV prevalence and genotype distribution have been described in different regions of the world, including Brazil (20). Thus, it is of utmost importance to conduct regional studies on the prevalence of HPV infection, including the identification and distribution of virus types. These studies are needed in order to evaluate the cost-benefit relation and the effectiveness expected from possible vaccination campaigns aimed at preventing infection from exposure to this pathogen and, consequently, cervical cancer.

The purpose of this study was to determine the prevalence of HPV infection, analyze the risk factors involved, and to identify and examine the distribution of the most prevalent types in a group of women enrolled in the cervical cancer screening program at Luis Antonio Hospital in Natal, Brazil.

\section{MATERIALS AND METHODS}

We analyzed cervical specimens of a group of women enrolled in the cancer screening program at the Luis Antonio Hospital in Natal, Brazil, between April 2000 and June 2001. The inclusion criteria were as follows: agreeing to participate in the study and answer a standardized epidemiological questionnaire, in addition to agreeing to undergoing uterine scraping for cytopathological analysis. Excluded were pregnant women, those who had had a miscarriage or delivery less than 60 days before the collection, those who had undergone hysterectomy, and those with mental deficit that would compromise the understanding and/or the responses when they filled out the questionnaire.

Two specimens containing exfoliated cells of the uterine cervix were collected from each patient using a cervical brush. One of these specimens was used to obtain a scraping which was stained by the Papanicolaou method and analyzed by cytopathological examination, based on the Bethesda system. The other was conditioned in a tube containing a preserving solution (PBS + vancomycin + nystatin) and sent to a laboratory where it was processed for DNA extraction and analyzed for HPV detection and typing.

The tubes containing the cervical specimens were submitted to vigorous agitation before removal of the brush and centrifuged at $3000 \times \mathrm{G}$ per $10 \mathrm{~min}$. The supernatant was removed and the resulting pellet was processed for DNA extraction, using rapid isolation of DNA from mammals, with proteinase $\mathrm{K}$ (23). The DNA samples were quantified by $0.8 \%$ agarose gel electrophoresis, and aliquots with around 30ng of DNA were submitted to a polymerase chain reaction (PCR) to amplify a 110 bp fragment of the human $\beta$-globin gene, using the primers $\mathrm{PCO} 3+/ \mathrm{PCO} 4+(22)$ to analyze the quality of target DNA.

All the samples analyzed by cytopathological examination that were $\beta$-globin positive were tested for HPV DNA detection by PCR using the primers MY09/11, which allowed us to amplify a fragment of approximately $450 \mathrm{bp}$ of a highly conserved region of the L1 gene from almost all mucosal HPV types (17). The PCR products were submitted to virus typing with dot blot hybridization (17), using specific probes for the following HPV types: $6,11,16,18,31,33,34,35,39,40,42,43,44,45,51,54,56$, and 58, marked with $\mathrm{P}^{32}$, isolated or in cocktails (14).

Statistical analysis to determine the association of each risk factor with HPV infection was performed using odds ratio (OR) with its respective $95 \%$ confidence intervals $(95 \% \mathrm{CI})$ and Pearson's $\chi^{2}$ test. The association between HPV infection and the results of cytological examination was analyzed using OR with its $95 \% \mathrm{CI}$. The software PEPI was used to perform all tests (12). The level of statistical significance was set at $p<0.05$.

The study protocol was approved by the Ethics Committee of the Universidade Federal do Rio Grande do Norte.

\section{RESULTS}

Analysis was performed on cervical specimens of 202 women, varying in age from 15 to 64 years (mean of 32 years), enrolled in the cancer screening program at the Luis Antonio Hospital, Natal, Brazil. Based on the cytopathological examination results, the patients were classified into two groups: the normal cytological group, composed of 110 women (54.5\%) with normal cytology or only benign alterations; and the cytological alteration group, composed of the remaining 92 (45.5\%) women, who presented squamous intraepithelial lesions (SIL). Of the women in the latter group, 78 (38.6\%) had low-grade lesions (LSIL) and 14 (6.9\%) had high-grade lesions (HSIL).

HPV DNA was found in $27(24.5 \%)$ of the cytologically normal women, $21(77.8 \%)$ of whom were infected by a single HPV type and $6(22.2 \%)$ by two types of virus. Of the women who had cytological alterations, $55(59.8 \%)$ were infected by HPV, $37(67.3 \%)$ of whom were infected by a single type of virus and $18(32.7 \%)$ had double infection. A significant difference was observed between the prevalence of HPV infection in the two groups $\left(\chi^{2}=25.8, p=0.000\right)$. The association between the presence of HPV DNA and the cytological examination results showed a 4.5 times greater likelihood for the occurrence of cytological alterations in HPV-infected women $(\mathrm{OR}=4.5 ; 95 \%$ CI:2.40-8.75), the reference being the women who tested negative for viral DNA. Women with infection by a single HPV type had risk of cytological alterations by around four times $(\mathrm{OR}=3.9$; 95\% CI: 1.94-8.10), whereas those with double infection had an increased risk of more than six fold (OR $=6.7$; 95\% CI:2.2720.83 ), the reference being the women who tested negative for viral DNA(Table 1). 
Table 1. Prevalence of HPV infection and virus type distribution, according to cytological findings.

\begin{tabular}{|c|c|c|c|c|c|c|c|}
\hline HPV Types & \multicolumn{2}{|c|}{ Normal Cytology } & \multicolumn{2}{|c|}{ Altered Cytology } & \multicolumn{2}{|c|}{ Total } & $\mathrm{OR}(95 \% \mathrm{CI})$ \\
\hline HPV - & 83 & 75.5 & 37 & 40,2 & 120 & 59,4 & Reference \\
\hline $\mathrm{HPV}+$ & 27 & 24.5 & 55 & 59,8 & 82 & 40,6 & $4,51(2,40-8,75)^{*}$ \\
\hline Single type & 21 & 19.1 & 37 & 40.2 & 58 & 28.7 & $3.95(1.94-8.10)^{*}$ \\
\hline 16 & 14 & 12.7 & 18 & 19.6 & 32 & 15.8 & \\
\hline 59 & 1 & 0.9 & 3 & 3.3 & 4 & 2.0 & \\
\hline $\mathrm{X}$ & 2 & 1.8 & 1 & 1.1 & 3 & 1.5 & \\
\hline Others types & 0 & 0.0 & 6 & 6.5 & 6 & 3.0 & \\
\hline Double Infection & 6 & 5.4 & 18 & 19.6 & 24 & 11.9 & $6.73(2.27-20.83)^{*}$ \\
\hline $16+18$ & 1 & 0.9 & 1 & 1.1 & 2 & 1.0 & \\
\hline $56+57$ & 2 & 1.8 & 8 & 8.7 & 10 & 5.0 & \\
\hline Others associations & 0 & 0.0 & 7 & 7.6 & 7 & 3.5 & \\
\hline
\end{tabular}

OR: Odds Ratio to cytological lesions; $95 \% \mathrm{CI}$ : 95\% Confidence interval; Distribution of HPV types: $\chi^{2}=13.75 ; \mathrm{p}=0.247 ; *$ Statistically significant.

Thirteen distinct HPV genotypes were identified. The virus type could not be identified in three samples, two of which were from cytologically normal women and one with cytological alterations. Almost all of the HPV genotypes detected belong to the high risk group, and no differences in HPV genotype distribution were observed between the two groups $(\mathrm{p}=0.24)$. HPV 16 was the most prevalent genotype in both groups, followed by HPV 58, in infection by a single type of the virus. In double infections the most frequent association was between HPV 56 and 57 , found in $1.8 \%$ and $8.7 \%$ of cytologically normal women and those with cytological alterations, respectively (Table 1).

The distribution of HPV infection prevalence by age showed indices of $33.3 \%$ in women $\leq 20$ years old and $43.7 \%$ in those between 21 and 30 years old, and a progressive reduction of this index in the two subsequent age groups, followed by another increase in women aged 51-60 years. However, we observed no significant differences between these indices in the different age groups, nor was any significant difference found between the prevalence of HPV infection in white and non-white women, despite the greater infection prevalence among the non-white women. The distribution of HPV infection cases according to marital status showed that single women had higher infection rates than did married women, but the difference was not statistically significant (Table 2 ).

The only risk factor that was strongly associated with HPV infection was multiple sexual partners $(\mathrm{OR}=2.02,95 \% \mathrm{CI}=1.09$ -
Table 2. Distribution of HPV infection according to sociodemographic factors analyzed.

\begin{tabular}{ccccc}
\hline \multirow{2}{*}{ Variable } & \multicolumn{3}{c}{ HPV infection } & \multirow{2}{*}{$\mathrm{P}$} \\
\cline { 2 - 3 } & Positive & Negative & $\%$ & \\
\hline Age group (years) & & & & \\
$\leq 20$ & 10 & 20 & 33.3 & 0.55 \\
$21-30$ & 28 & 36 & 43.7 & \\
$31-40$ & 28 & 45 & 38.4 & \\
$41-50$ & 6 & 12 & 33.3 & \\
$51-60$ & 9 & 6 & 60.0 & \\
$\geq 61$ & 1 & 1 & 50.0 & \\
Ethnic group & & & & \\
White & 64 & 99 & 39.3 & 0.43 \\
Non-white & 18 & 21 & 46.2 & \\
Marital Status & & & & \\
Single & 20 & 17 & 54.1 & 0.06 \\
Married & 61 & 104 & 37.0 & \\
\hline
\end{tabular}

P: $p$ value obtained by $\chi^{2}$ test; $\%$ : Prevalence of HPV infection.

3.74). The other variables reported in the literature as being risk factors for HPV infection, such as age at first sexual intercourse, parity, and smoking, had no association with the presence of viral DNA, the reference being the non-infected women. All 
women who used oral contraceptives for more than 11 years were HPV infected. However, the difference was not significant, when compared with non-users (Table 3 ).

\section{DISCUSSION}

The results showed that a significant portion of cytologically normal women were infected by HPV. They had practically the same prevalence index as that found in Nigerian women (7); slightly higher than that observed in women in Recife, northeast of Brazil $(9,16)$; double that found in Chile, Argentina, and Colombia $(7,10)$; and five times higher than the mean prevalence of women in the Netherlands, Italy, and Spain (7). This high prevalence of HPV infection in asymptomatic women could be due to the high proportion of individuals who started sexual activity before the age of 18 , when they would have presented increased biologic vulnerability to this virus $(11,24)$. Besides, most infections were caused by high-risk HPV, having a greater capacity to develop persistent infection, which may remain asymptomatic for an indeterminate time.

The prevalence of HPV 16 infection in cytologically normal women in this study was similar to that described for women in
Recife (16), but higher than that found in a wider study (7), in which samples from women of various parts of the world were analyzed. This suggests that Northeastern women could be exposed to increased risk of developing cervical cancer than those from other regions or countries.

In the women with cytological alterations, the overall prevalence of HPV infection was practically the same as that observed in African women (8), and similar to that of women from Brasilia, Brazil, but higher than that found in women from Recife $(9,16)$, and lower than the prevalence in women from Europe, and Central and South America (8). These differences can be attributed to variations in the rates of HPV prevalence observed between different populations, as well as varying study designs and method sensibility (8).

We found association between HPV infection and the presence of cytological alterations, both in women with infections caused by a single virus type and in those with double infection. The simultaneous infection by two HPV types increased nearly seven-fold the likelihood of occurrence of cytological alterations, and the infection caused by a single type of virus increased nearly four-fold. These results corroborate those obtained in a study conducted with women

Table 3. Odds ratio (OR) for the association between selected variables and HPV infection.

\begin{tabular}{|c|c|c|c|c|c|}
\hline \multirow{2}{*}{ Risk Factor } & \multicolumn{3}{|c|}{ HPV Infection } & \multirow{2}{*}{ OR $(95 \%$ IC) } & \multirow{2}{*}{$\mathrm{p}$} \\
\hline & Positive & Negative & $\%$ pos & & \\
\hline \multicolumn{6}{|c|}{ Age at first sexual intercourse } \\
\hline$\leq 17$ & 47 & 62 & 43.1 & $1.11(0.51-2.45)$ & 0.770 \\
\hline $18-20$ & 18 & 33 & 35.3 & $1.15(0.44-3.02)$ & 0.750 \\
\hline$\geq 21$ & 17 & 25 & 40.5 & Reference & - \\
\hline \multicolumn{6}{|c|}{ Age at first pregnancy } \\
\hline Never pregnant & 13 & 15 & 46.4 & Reference & - \\
\hline$\leq 17$ & 15 & 22 & 40.5 & $0.79(0.26-2.38)$ & 0.640 \\
\hline $18-20$ & 28 & 44 & 38.9 & $0.73(0.28-1.94)$ & 0.490 \\
\hline$\geq 21$ & 26 & 39 & 40.0 & $0.77(0.29-2.06)$ & 0.560 \\
\hline \multicolumn{6}{|c|}{ Oral contraceptive use (years) } \\
\hline Never & 34 & 41 & 45.3 & Reference & - \\
\hline $1-5$ & 35 & 65 & 35.0 & $0.65(0.34-1.25)$ & 0.170 \\
\hline $6-10$ & 9 & 14 & 39.1 & $0.78(0.27-2.21)$ & 0.600 \\
\hline$\geq 11$ & 4 & 0 & 100.0 & $4.69(0.72-\infty)$ & 0.098 \\
\hline \multicolumn{6}{|c|}{ Multiple sexual partner } \\
\hline Yes & 42 & 41 & 50.6 & $2.02(1.09-3.74)$ & $0.023^{*}$ \\
\hline No & 40 & 79 & 33.6 & Reference & - \\
\hline \multicolumn{6}{|l|}{ Smoking } \\
\hline Yes & 11 & 19 & 36.7 & $0.82(0.33-1.96)$ & 0.792 \\
\hline No & 71 & 101 & 41.3 & Reference & - \\
\hline
\end{tabular}

\footnotetext{
* Statistically significant; P: p value obtained by $\chi^{2}$ test; 95\% CI: 95\% Confidence Interval.
} 
in São Paulo, Brazil (25). The higher frequency of cytological alterations in women with double HPV infection might be due to HPV types interaction or action synergistically to induce lesion development or progression.

The distribution of the HPV genotypes found in the women of this study exhibits a similar pattern to that described by women in Central and South American countries $(7,8)$, with some variations. The distribution of HPV genotypes, in order of prevalence, for the women with cytological alterations was similar to that described for Recife and Brasilia $(4,9,16)$, in relation to HPVs 16,58 , and 18 , but different from HPVs $31,45,52$, and 59. It was also similar to the distribution described for Africa and Central and South America (8), in relation to HPVs 16, 58, 52,53 , and 18 , but different from HPVs $33,35,45$, and 59 . HPV 59 was found only in women from Natal and from Africa, where it was in third and eighth place in prevalence, respectively.

The distribution of cases of HPV infection according to age groups showed a higher prevalence in the 21-30 age group, followed by a decrease in the subsequent age groups, and another increase in women between 51 and 60 years, findings similar to those observed in other studies $(1,24)$. It is believed that this is due to the acquisition of an adaptive immune response developed over time, which could resolve the infection or maintain the virus in latency, followed by a reactivation in the post-menopause period caused by a reduction in specific immunity, or the acquisition of a new infection. The non-white women had a prevalence of HPV infection slightly higher than that of white women, but the difference was not significant. We found a higher HPV infection prevalence in single women than in married women, with a $p$ value near the limit of statistical significance. This is probably due to the absence of a stable relationship, favoring a higher variability of sexual partners of the single women. The only risk factor analyzed that had a strong association with HPV infection was multiple sexual partners, a finding similar to that of other studies conducted in Chile (10) and in Porto Alegre, Brazil (19).

These results lead us to conclude that HPV infection, whether the single type or by the association of two types of virus, is an important risk factor for the occurrence of cervical epithelium alterations. In women with cytological alterations, the prevalence of HPV 16 infection was practically the same as that described for the Americas. Nearly all the other virus genotypes detected belong to the high-risk group, which shows the importance of cervical cancer screening programs. There is a similarity in the distribution of some HPV genotypes found in Natal with that in Recife and Brasilia. However, we observed important differences in HPV 59 and 45 (the third and eighth most prevalent, respectively, in women from Natal) that were not detected in women from Recife and Brasilia, underscoring the need for local studies. It is worth pointing out that more than $40 \%$ of the HPVpositive women were infected by virus genotypes not contemplated in the two vaccines currently available. Thus, although these vaccines represent a great advance in cervical cancer prevention, they still present limitations that must be overcome, given the existence of multiple virus types and the variations in their geographic distributions.

This study allowed identify differences in relation to prevalence of HPV infection and virus genotype distribution even in the same geographic region, justifying the need of more local studies for the cost-benefit analysis and the expected efficacy of a possible HPV vaccination campaign

\section{ACKNOWLEDGEMENTS}

To Dr. Luisa Lima Villa and her team at São Paulo Branch of the Ludwig Institute for Cancer Research, Brazil, for the technical-scientific assistance provided and for performing viral typing, and to CNPq for the financial support.

\section{RESUMO}

\section{Infecção por papilomavírus humano em mulheres atendidas em um serviço de prevenção ao câncer do colo do útero em Natal, Brasil}

Foram analisados espécimes cervicais de 202 mulheres, com idade variando de 15 e 64 anos, atendidas no Hospital Luis Antonio, Natal-RN, objetivando determinar a prevalência do HPV, identificar genotipos do vírus e possíveis fatores de risco para a infecção por esse patógeno, em mulheres atendidas em um serviço de rastreamento do câncer do colo do útero. De cada paciente foram coletados dois espécimes: um destinado ao exame citológico e outro para detecção do HPV por PCR, com tipagem por hibridização "dot blot". Das pacientes incluídas no estudo, $54,5 \%$ apresentaram citologia normal e $45,5 \%$ tinham alterações citológicas. HPV foi detectado em $24,5 \%$ das mulheres com citologia normal, e em $59,8 \%$ das que apresentaram citologia alterada. Tanto a infecção por um único tipo de HPV, quanto a infecção simultânea por dois tipos diferentes do vírus aumentaram a chance de ocorrência de alterações citológicas. Foram identificados treze tipos de HPV, a maioria de alto risco. Nas infecções por um único tipo, o HPV 16 foi o mais prevalente, seguido do HPV 58. Na infecção dupla a associação mais freqüente foi entre HPV 56 e 57. A prevalência do HPV nas mulheres com citologia normal foi superior a relatada para países de todos os continentes, exceto África. Nas mulheres com alterações citológicas observou-se resultado inverso. A distribuição dos tipos de HPV foi semelhante à descrita para Américas, com algumas diferenças. Dos fatores de risco analisados, o relacionamento sexual com múltiplos parceiros foi o único que apresentou associação com a presença de infecção por HPV.

Palavras-chave: Papilomavírus humano, Doenças do colo do útero, Epidemiologia, Prevalência, Fatores de risco. 


\section{REFERENCES}

1. Baseman, J.G.; Koutsky, L.A. (2005). The epidemiology of human papillomavirus infections. J. Clin. Virol., 32 Suppl 1, S16-24.

2. Bosch, F.X.; de Sanjosé, S. (2003). Chapter 1: Human Papillomavirus and Cervical Cancer - Burden and Assessment of Causality. J. Natl. Cancer Inst. Monographs, 31, 3-13.

3. Bosch, F.X.; Lorincz, A.; Muñoz, N.; Meijer, C.J.L.M.; Shah, K.V. (2002). The causal relation between human papillomavirus and cervical cancer. J. Clin. Pathol., 55, 244-265

4. Câmara, G.N.L.; Cerqueira, D.M.; Oliveira, A.P.G.; Silva, E.O.; Carvalho, L.G.S.; Martins, C.R.F. (2003). Prevalence of human papillomavirus types in women with pre-neoplastic and neoplastic lesions in the Federal District of Brasil. Mem. Inst. Oswaldo Cruz, 98 (7), 879-883.

5. Castle, P.E.; Schiffman, M.; Herrero, R.; Hildesheim, A.; Rodriguez, A.C.; Bratti, M.C.; Sherman, M.E.; Wacholder, S.; Tarone, R.; Burk, R.D. (2005). A prospective study of age trends in cervical human papillomavirus acquisition and persistence in Guanacaste, Costa Rica. J. Infect. Dis., 191 (11), 1808-1816.

6. Clifford, G.; Franceschi, S.; Diaz, M.; Muñoz, N.; Villa, L.L. (2006). Chapter 3: HPV type-distribution in women with and without cervical neoplastic diseases. Vaccine, 24 Suppl 3, S26-34.

7. Clifford, G.M.; Gallus, S.; Herrero, R.; Muñoz, N.; Sniiders, P.J.F.; Vaccarella, S.; Anh, P.T.; Ferreccio, C.; Hieu, N.T.; Matos, E.; Molano, E.; Rajkumar, R.; Ronco, G.; Sanjose, S.; Shin, H.R.; Sukvirach, S.; Thomas, J.O.; Tunsakul, S.; Meijer, C.J.; Franceschi, S. IARC HPV Prevalence Surveys Study Group. (2005a). Worldwide distribution of human papillomavirus types in cytologically normal women in the International Agency for Research on Cancer HPV prevalence surveys: a polled analysis. Lancet., 366, 991-998.

8. Clifford, G.M.; Rana, R.K.; Franceschi, S.; Smith, J.S.; Gough, G.; Pimenta, J.M. (2005b). Human Papillomavirus Genotype Distribution in Low-Grade Cervical Lesions: Comparison by Geographic Region and with Cervical Cancer. Cancer Epidemiol. Biomarkers Prev., 14, 1157-1164.

9. Da Silva, T.T.; Guimarães, M.L.; Barbosa, M.I.C.; Pinheiro, M.F.G.; Maia, A.F. (2006). Identificação de tipos de papilomavírus e de outros fatores de risco para neoplasia intra-epitelial cervical. Rev. Bras. Ginecol. Obst., 28 (5), 285-291.

10. Ferreccio, C.; Prado, R.B.; Luzoro, A.V.; Ampuero, S.L.; Snijders, P.J.F.; Meijer, C.J.L.M.; Vaccarella, S.V.; Jara, A.T.; Puschel, K.I.; Robles, S.C.; Herrero, R.; Franceschi, S.F.; Ojeda, J.M. (2004). Population-Based Prevalence and Age Distribution of Human Papillomavirus Among Women in Santiago, Chile. Cancer Epidemiol. Biomarkers Prev., 13 (12), 2271-2276.

11. Frega, A.; Stentella, P.; de Ioris, A.; Piazze, J.J.; Fambrini, M.; Marchionni, M.; Cosmi, E.V. (2003). Young women, cervical intraepithelial neoplasia and human papillomavirus: risk factors for persistence and recurrence. Cancer Lett., 196 (2), 127-134.

12. Gahlinger, P.M.; Abramson, J.H. (1995). Computer programs for epidemiologic analysis: PEPI. Stone Mountain, USD.

13. Herrero, R.; Hildesheim, A.; Bratti, C.; Sherman, M.E.; Hutchinson, M.; Morales, J.; Balmaceda, I.; Greenberg, M.D.; Alfaro, M.; Burk, R.D.; Wacholder, S.; Plummer, M.; Schiffman, M. (2000). Population-based study of human papillomavirus infection and cervical neoplasia in rural Costa Rica. J. Natl. Cancer Inst., 92, 464-474.

14. Jacobs, M.V.; de Roda Husman, A.M.; van den Brule, A.J.; Snijders, P.J.; Meijer, C.J.; Walboomers, J.M. (1995). Group-specific differentiation between high- and low-risk human papillomavirus genotypes by general primer-mediated PCR and two cocktails of oligonucleotide probes. J. Clin. Microbiol., 33, 901-905.

15. Kjaer, S.K.; Svare, E.I.; Worm, A.M.; Walboomers, J.M.; Meijer, C.J.; van den Brule, A.J. (2000). Human papillomavirus infection in Danish female sex workers. Decreasing prevalence with age despite continuously high sexual activity. Sex. Transm. Dis., 27 (8), 438-445.

16. Lorenzato, F.; Ho, L.; Terry, G.; Singer, A.; Santos, L.C.; Batista, R.L.; Lubambo, T. (2000). The use of human papillomavirus typing in detection of cervical neoplasia in Recife (Brazil). Int. J. Gynecol. Cancer, 10 (2), 143-150.

17. Manos, M.M.; Ting, T.; Wright, D.K.; Lewis, A.J.; Broker, T.R.; Wolinsky, S.M. (1989). The use of polymerase chain reaction amplification for the detection of genital human papillomavirus. Cancer Cell. Mol. Diagnost. Hum. Cancer, 7, 209-214.

18. Muñoz, N.; Bosch, F.X.; de Sanjosé, S.; Herrero, R.; Castellsagué, X.; Shah, K.V.; Snijders, P.J.F.; Meijer, C.J.L.M. (2003). Epidemiologic Classification of Human Papillomavirus Types Associated with Cervical Cancer. N. Engl. J. Med., 348, 518-527.

19. Naud, P.; Matos, J.; Hammes, L.; Stuckzynski, J.; Brouwers, K.; Magno, V.; Dias, E.; Crusius, P.; d'Avila, A.; Campos, C.; Costa, M.; Hoblik, M.; Marc, C.; Marroni, R.; Syrjanen, K. (2006). Factors predicting intermediate endpoints of cervical cancer and exposure to human papillomavirus (HPV) infections in young women screened as potential targets for prophylactic HPV vaccination in south of Brazil. Eur. J. Obstet. Gynecol. Reprod. Biol., 124 (1), 110-118.

20. Rabelo-Santos, S.H.; Zeferino, L.; Villa, L.L.; Sobrinho, J.P.; Amaral, R.G.; Magalhães, A.V. (2003). Human papillmavirus prevalence among women with cervical intraepithelial neoplasia III and invasive cervical cancer from Goiânia, Brazil. Mem. Inst. Oswaldo Cruz, 98 (2), 181-184.

21. Ronco, G.; Ghisetti, V.; Segnan, N.; Snijders, P.J.; Gillio-Tos, A.; Meijer, C.J.L.M.; Merletti, F.; Franceschi, S. (2005). Prevalence of human papillomavirus infection in women in Turin, Italy. Eur. J. Cancer, 41 (2), 297-305.

22. Saiki, R.K.; Scharf, S.; Faloona, F.; Mullis, K.B.; Horn, G.T.; Erlich, H.A.; Arnheim, N. (1985). Enzymatic amplification of beta-globin genomic sequences and restriction site analysis for diagnosis of sickle cell anemia. Science, 230, 1350-1354.

23. Sambrook, J.; Russel, D.W. (2001). Molecular cloning: a laboratory manual. 3rd. ed., Cold Spring Harbor Laboratory Press, New York.

24. Trottier, H.; Franco, E.L. (2006). The epidemiology of genital human papillomavirus infection. Vaccine, 24 Suppl 1, S1-15.

25. Trottier, H.; Mahmud, S.; Costa, M.C.; Sobrinho, J.P.; Duarte-Franco, E.; Rohan, T.E.; Ferenczy, A.; Villa, L.L.; Franco, E.L. (2006). Human papillomavirus infections with multiple types and risk of cervical neoplasia. Cancer Epidemiol. Biomarkers Prev., 15 (7), 1274-1280.

26. Walboomers, J.M.; Jacobs, M.V.; Manos, M.M.; Bosch, F.X.; Kummer, J.A.; Shah, K.V.; Snijders, P.J.F.; Peto, J.; Meijer, C.J.L.M.; Muñoz, N. (1999). Human papillomavirus is a necessary cause of invasive cervical cancer worldwide. J. Pathol., 189 (1), 12-19. 